\title{
THE HISTORICAL CONTEXT OF CONSTITUTIONAL CHANGE IN GANADA
}

\author{
Filippo SABETTI*
}

\section{Ut incepit fidelis sic permanet? $†$}

The British North America Act (BNA Act)" has been "patriated." At last, Canadians have their own basic law. The historical context of this constitutional change is the history of a political system that did not work as its creators had intended, of constitutional reform efforts that ended in stalemate, and of analysts "fallen into speaking the language of doubt when describing their society." 2 Why, then, should we bother about the past? The past is important for three simple reasons: 1) A large proportion of the reasoning still employed in the analysis of contemporary government and politics rests explicitly or implicitly on an interpretation of the historical record of constitutional change; past experience could discredit this current reasoning; 2) The modelling and remodelling of constitutional arrangements are well enough documented to suggest conclusions which could become plausible working hypotheses about constitutional choice; and 3) The Constitution of $1982^{3}$ could be checked against the working hypotheses about past experiences in order to explain its successful patriation and to predict its applicability for resolving old problems. But the method of the attack of the historical record will determine the utility of the analysis.

First, the importance of constitutionalism for a liberal democratic society is well enough established to require no extended elaboration or defense. ${ }^{4}$ Laws, regulations, organizations, and property rights - the institutional arrangements in society that create incentive systems through which citizens and public officials

\footnotetext{
Copyright (C) 1983 by Law and Contemporary Problems.

* Associate Professor of Political Science, McGill University. Many essential ingredients to the preparation of this article have been contributed by the intellectual exchange I have shared with colleagues associated with the Workshop on Covenant and Politics organized by Daniel J. Elazar at the Center for the Study of Federalism, Temple University, with colleagues participating in the McGill-Duke Symposium on the Reform of the Canadian Constitution in 1982 organized by Paul Davenport and Richard $\mathrm{H}$. Leach at Duke University, and Charles Tilly's work on European state making. I am particularly grateful to Christopher Armstrong, Marcel Caya, J.R. Mallory, Kenneth H. Norrie, Mario R. Pietrangeli, David E. Smith, Mark Sproule-Jones, and John H. Thompson for suggestions. Vincent di Norcia was especially thoughtful in his extended comments. This article draws on research supported by a sabbatical leave fellowship from the Humanities and Social Science Research Council of Canada in 1980-81, help which I also wish to acknowledge.

† "As loyal she began, so shall she remain?" With apologies to the Province of Ontario.

1. British North America Act, 1867, 30 \& 31 Vict., ch. 3 [hereinafter cited as BNA Act].

2. D. Bell \& L. Tepperman, The Roots of Disunity, A look at Canadian Political CulTURE 6 (1979).

3. Constitution Act, 1982.

4. See generally Maddox, A Note on the Meaning of 'Constitution', 76 AM. POL. SCI. REV. 805 (1982); Sartori, Constitutionalism: A Pteliminary Discussion, 56 AM. POL. SCI. REV. 853 (1962).
} 
operate and think politically - are, in the final analysis, established and maintained by constitutional arrangements. These constitutional arrangements determine who may exercise governmental authority, what limits (if any) are placed on this authority, and the kinds of agreements which must exist between government decisionmakers before laws, regulations, and organizations are changed. 5 "The study of politics must, therefore, very largely consist of the examination of the ways in which constitutional and political institutions, and the social forces and movements in a particular society, interact with each other; of the limits upon the extent to which stable constitutional modes of behavior can be developed and maintained; of the effects they can have on moulding behavior."6 By drawing upon the distinction between individuals engaged in constitutional decisionmaking and individuals pursuing their relative advantages within institutions, modern public choice scholars have been able to resolve several paradoxes inherent in collective or social choices and to provide a better understanding of the strategic opportunities afforded to future individual decisionmakers by different types of decision rules or decisionmaking structures. ${ }^{7}$

Second, the historical context of the Canadian Constitution of 1982 must be defined. If the span of time is very long, it is possible to bias the analysis toward evolutionary and deterministic explanations that are very difficult to confirm or disprove. Almost all the work on Canadian development before World War II is plagued with these difficulties. ${ }^{8}$ If the span of time is very short, it is impossible to detect trends. It was not too long ago that distinguished students of Canadian history and politics were dismissing both "provincial rights" as a passing phase in national development and the Supreme Court as a useful agency for conflict management in federal-provincial relations. Beginning the analysis with the constitutional settlement of 1867 , known as Confederation, seems appropriate on at least two counts. The span of time involved, being neither very long nor very short, avoids the two extremes. Moreover, Confederation was, all at once, the constitutional change that ended the deadlocked union of 1841 and the status quo that triggered (or deadlocked) constitutional changes for more than a century.

Third, the object of this article is not simply to explain why, almost since Con-

5. Sec, e.g., Kiser \& Ostrom, The Three Worlds of Action: A Metatheoretical Synthesis of Institutional Approaches, in STRATegies OF Polmtical Inquiry 179-222 (E. Ostrom ed. 1982); Sproule-Jones, Institutions, Constitutions and Public Policies: A Public Choice Overview, in Canadian Public Policy: A Comparative APPROACH 38 (M. Atkinson \& W. Chandler eds. 1983).

6. M. Vile, Constitutionalism and the Separation of Powers 314 (1967).

7. See, e.g., J. Buchanan \& G. Tullock, The Calculus of Consent (1962); V. Ostrom, The Intellectual Crisis in American Public Administration (2d ed. 1974); Sproule-Jones, Public Choice Theory and Natural Resources: A Methodological Explication and Critique, 76 AM. POL. SCI. REV. 790 (1982). Buchanan and Tullock were able to show that it would be a Pareto-efficient move for individuals at the constitutional stage to opt for a set of decision rules that does not meet the condition of Pareto efficiency in taking collective actions. Ostrom has advanced the argument regarding democratic administration as an alternative to bureaucratic administration. Sproule-Jones has placed in sharp relief the methodological criterion of logical consistency for the impetus behind the growth of the public choice paradigm at the interface of political science, economics, public administration, and law. J. RAWLS, A THEORY OF JUSTICE (1971) may be viewed as a more philosophic treatise of this paradigm.

8. See, e.g., C. Berger, The Writing of Canadian History, aspects of English Historical WRITING: $1900-1970$ (1976). 
federation, Canadians have been in the midst of some form of constitutional crisis-what historian Goldwin Smith in 1891 characterized as "the Canadian question."' It is also to evaluate that chain of crises. As Mark Sproule-Jones suggests, "The challenge is not only to explain who wins and who loses, but to develop new norms to assess the place of the individual in the organization of the state." 10 The principal problem that confronts people in the design and redesign of constitutional arrangements is to determine how values and principles articulated in correlative forms can be expected to yield different results. The attempts of many revolutionaries to create new societies and new social orders suggest that it is entirely possible for fallible human beings to formulate explanations and to use those explanations for undertaking political and social experiments that do not work in anticipated ways. The reiteration of unitary and hierarchical principles of organization led de Tocqueville in his recollections of the 1848 revolt to the conclusion that "in France there is only one thing that we cannot make: a free government; and only one thing that we cannot destroy: centralization."11 But this is no argument for skepticism, merely one against pretensions to omniscience. By disaggregating the problem of social organization between constitutional choice and governmental decisionmaking, Hobbes was able to anticipate the implications that this distinction has for the way evaluative analysis is conducted. Hobbes observed that when constitutional failures occur "the fault is not in men, as they are the matter; but as they are the makers and orderers of [commonwealths]." 12

The remainder of the article will proceed as follows. First, the Canadian political tradition and the making of Confederation is discussed. Then, the factors that led to the remodelling of the 1867 constitutional settlement are traced and examined. This remodelling suggests three broad phases of constitutional change. The first phase, beginning in the 1870's and ending in 1927, led to the transformation of provincial governments from glorified municipalities to agents of constitutional choice placed alongside the federal government. The second phase, beginning in 1927 and ending in the late 1970's, involved efforts by the provincial and federal governments to determine jointly constitutional arrangements for both the full patriation of the BNA Act and the provision of public services. The third phase, beginning in 1980 with the attempt by the federal government to unilaterally patriate the constitution and continuing to date, led to the proclamation of the new Canadian Constitution in 1982. The first and second phases of constitutional change are assessed. Finally, the significance of the Canadian Constitution of 1982 for the resolution of old problems and issues while critical features of Canadian governance remain unchanged is explored.

I

\section{The Canadian Political Tradition and Confederation}

As Frank R. Scott, a leading student in Canadian federalism and for many

9. G. Smith, Canada and the Canadian Question (1891).

10. Sproule-Jones, supra note 5 , at 28

11. A. De Tocqueville, Recollections xviii (J. Mayer \& A. Kerr eds. 1971)

12. T. Hobbes, Leviathan 237 (M. Oakeshott ed. 1962)(1st ed. London 1651). 
years professor of constitutional law at McGill University, suggests, "Like most political events in which the chief actors profess high aims, Confederation had its more materialistic aspects."13 These ranged from the need to provide a more secure basis to certain financial and railway interests and the desire to facilitate the westward expansion of Upper Canada, to the threat to survival engendered by the vicissitudes of the American Civil War. "Yet even when all allowances necessary (to take these factors into account) are duly made, the political fact of the 1867 union remains. A new country was created . . . ."14

The terms of the 1867 constitutional settlement combined federal and unitary principles of organization while the settlement itself was created by a statute of the imperial parliament, the BNA Act. ${ }^{15}$ " $[\mathrm{T}]$ he Canadian Constitution at the time of its creation presented to the world of political science a novel combination of constitutional principles-a monarchical federation based upon legislative supremacy under a single external sovereign."16 It is probably true that without the Francophone community, the creation of this new country would have proceeded along centralized lines-in the words of Sir John A. Macdonald, "one government and one parliament, legislating for the whole of these peoples . . . the cheapest, the most vigorous, and the strongest system of government we could [have] adopt[ed]."17 As Ormsby suggests, "[T]he survival of French Canada, despite the deliberate attempt to overwhelm it in a union of the two Canadas, demanded the emergence of a federal concept."18

But Confederation was not a sharp break with the history of British North America since the conquest of New France in 1763. It took place within the British Empire and the North American Loyalist tradition to the Crown-with a particular twist. The mixed and balanced nature of parliamentary sovereignty that was the hallmark of English constitutional tradition and thought did not have time to emerge as a practice and doctrine in Canada. ${ }^{19}$ The colonial governmental system was replaced in the 1840's by "responsible government," the socalled Westminster model of government. ${ }^{20}$ As a result, choices about basic policies and the availability of different organizational arrangements for pursuing new developmental opportunities continued to reside with members of the executive in control of the House of Commons. Research for The Developing Canadian Commu-

13. Scott, Political Nationalism and Confederation, in ESSAYS ON THE CONSTITUTION: AspeCts OF CANADIAN LAW AND POLITICS 4 (1977).

14. Id.

15. See supra note 1 .

16. Scott, The Development of Canadian Federalism, in Essays ON THE CONSTTTUTION: Aspects OF Canadian Law and Politics 35 (1971). See also Hodgins, The Plans of Mice and Men, in Federalism in Canada ANd Australia-The Early Years 3, 13 (1978).

17. John A. Macdonald, quoted in The Confederation Debates in the Provinces of Canada, 1865, The Carlton Library No. 2, at 40 (P. Waite ed. 1963).

18. W. Ormsby, The Emergence of the Federal Concept in Canada, 1839-1845, at 36 (1969); see id. at 120-21.

19. M. VILE, supra note 6 , ch. 8.

20. See generally Mallory, Responsive and Responsible Govemment, 12 Transactions of the RoYal Society of Canada, Series IV, at 207 (1974); Mallory, Confict Management in the Canadian Federal System, LaW \& Contemp. Probs., Summer 1981, at 231-32. 
nity ${ }^{21}$ led S.D. Clark to conclude that

what has been thought of in Canada as an orderly process of adapting political institutions to changing circumstances has actually represented an effort to hold in check the kind of democratic forces which were growing up from within the Canadian community. Responsible government developed in reaction rather than in response to the true democratic spirit of the Canadian people. ${ }^{22}$

Just as the emergence of the federal concept assured the survival of French Canada, so the reiteration of responsible government in 1867 assured the continuation of the executive-centered system of government of colonial times.

The fusion of different and antithetical constitutional principles suggests in part that the Confederation Fathers did not give adequate consideration to the relationship between the principles and forms used to fashion a united Canada nor to the consequences that were apt to follow. An examination of some of the fundamental features of the 1867 constitutional settlement suggests why there was little awareness that the "novel combination of constitutional principles" could give rise to consequences that radically deviated from expectations.

First, the Canadian constitutional system through sections 40, 90, 91, 92, 93, 95, and 132 of the BNA Act gave the national government formidable power and influence over provincial governments to place the latter in a colonial subordination to the national government. Why did Upper Canada Fathers of Confederation like George Brown, who were so pro-Upper Canada localism, ${ }^{23}$ choose to support this system of government?

Christopher Armstrong, in his recent book on Ontario's relations with the federal government between 1867 and 1942, suggests possible reasons. ${ }^{24}$ It is true that Brown spoke for the businessmen of Toronto who saw in a strong central government a prerequisite for economic growth and western expansion, as well as for the Upper Canada farmers. But Brown was convinced that the strong Ontario representation in the Senate and the House, to which a rising population entitled the province, and the prospects of sending loyal Reformers to both chambers provided sufficient safeguards for the vital interests of their locality. Institutions and individuals would see to it that Ontario's local intersts were not neglected. But the Upper Canada Reformer did not adequately consider that the powers of a prime minister over his cabinet and party and the convention of collective responsibility and party solidarity could render Ontario's representation in Parliament almost nugatory. "As a result, George Brown and his Reform supporters had no qualms about leading Upper Canadians into a highly centralized union, almost a legislative union of the type desired by John A. Macdonald."25

Alternatively, "a Constitution similar in Principle to that of the United Kingdom"26 combined with federal arrangements meant, in effect, legislative and

21. S. Clark, The Developing Canadian Communtty (2d ed. 1968).

22. Id. at 208.

23. See generally Jones, Localism and Federalism in Upper Carada to 1865, in FEDERALISM IN GANADA AND Australia: The Early Years 19 (1978).

24. See C. ARmstrong, The Politics of Federalism: Ontario's Relations with the Federal GOVERNMENT, 1867-1942 (1981).

25. Id. at 12 .

26. BNA Act, supra note 1, preamble. 
administrative supremacy at the provincial as well as the federal level of government. But the powers of the federal government over the provinces served to obscure and confound the implications of provincial legislative supremacy for national government dominance. As a result, "no one realized that [this constitution] contained in embryo a principle of the 'co-ordinate sovereignty' of general and local governments, the inevitable result of which would be sovereign provincial powers and the political cry of 'provincial rights.' "27

Second, though French-speaking communities existed, and were recognized as such beyond Quebec, French received no written guarantee outside Quebec. The absence of such guarantee has often been used by most Anglophone analysts to support the claim that Confederation did not represent the conscious effectuation of a compact between the English and the French as the two founding peoples of Canada. Some Anglophone analysts have, however, noted that " $[\mathrm{t}]$ he argument from evidence (or rather from lack of it) that the fathers [of Confederation] made no open and acknowledged commitment to give legal status to the French language from coast to coast has not and cannot lay to rest the idea of the 'spirit of Confederation" " as an implied bicultural compact. ${ }^{28}$ This implied bicultural compact received, it is further alleged, confirmation in the 1870 Manitoba Act $^{29}$ and the 1875 Act establishing the Northwest Territories. ${ }^{30}$ Unfortunately, the existence of a bicultural compact between the English and the French is difficult to confirm or disprove. ${ }^{31}$ Covenantal or providential theology did not even provide the basis for an emergent English Canadian nationalism. ${ }^{32}$ Other, less controversial, factors can be adduced to account for the absence of a written guarantee for the French outside Quebec. These are: 1) section 93 of the BNA Act, entitling the national parliament to enact remedial legislation in support of the educational rights of a provincial denominational minority; 2) at the time "minorities were more concerned about potential threats to religious rights than to linguistic rights;"33 and 3) religious rights were then in part perceived as cultural rights. ${ }^{34}$

Third, the BNA Act contained no formula or machinery for its own amendment. The standard explanation is that by the 1860's the British Parliament "still regarded itself as the supreme constituent power in the British Empire, and it would not lightly have been persuaded to grant a wholly Canadian procedure of

27. W. Morton, The Critical. Years, The Union of British North America, 1857-1873, at 177 (1964).

28. Heintzman, The Spint of Confederation: Arofessor Creighton, Biculturalism, and the Use of History, 52 CAN. Hist. Rev. 245, 249 (1971); see also Stanley, Act or Pact: Another Look at Confederation, 1956 REP. ANN. Meeting Can. Hist. A. 1.

29. The Manitoba Act, 1870, 33 Vict., ch. 3.

30. Act to amend and consolidate the Northwest Territories, 1875, 38 Vict., ch. 49.

31. See generally F. Sabetti, Covenant Language in Canada: Continuity and Change in Political Discourse 4-12 (1980) (Workshop on Covenant and Politics Working Paper No. 37, Temple University Center for the Study of Federalism).

32. Wise, God's Peculiar Peoples, in The Shield of Achilles: Aspects of Canada in the VictoRIAN AGE 36, 59 (W. Morton ed. 1968).

33. R. CoOK, French Canada and Confederation: The Quest for Equality, in The MAPLe LEAF Forever, Essays on Nationalism and Politics in Canada 68, 72 (1971).

34. See generally A. Siegried, The Race Question IN Canada 19-105 (1906 \& photo. reprint 1966). 
amendment."35 The absence of an amending procedure was no problem as long as Confederation worked as its creators intended.

For these reasons, Confederation did not appear at creation to be "the ambiguous bargain" it was later thought to be. ${ }^{36}$ Led by the prevailing conception of political rule and biased toward hierarchical arrangements, Confederation Fathers expected the 1867 constitutional settlement to work as it should.

\section{II}

\section{The First Phase of Constitutional Change}

The rising dominance of provincial legislatures and parliament by disciplined mass parties strengthened simple majority rule and legislative supremacy of the executive. By the 1870's, federal and provincial autonomy joined with federal and provincial supremacy to reveal critical shortcomings in the design of Confederation. Pressures for changing the 1867 constitutional settlement came from provincial governments and interests. In the absence of an amending formula, the compact of provinces emerged as "the political formula" 37 for changing the 1867 constitution. The consequences of the compact of provinces for the Francophone communities outside Quebec led, in turn, to other pressures for change, using "the compact of peoples" as the moral and metaphysical foundations of Confederation.

\section{A. The Compact of Provinces}

Judge T.J.J. Loranger in his Letters upon the Interpretation of the Federal Constitution Known as the British North America Act ${ }^{38}$ offered one of the most articulate and wellknown elaborations of the compact of provinces as the legal basis for constitutional change. Loranger's contention was grounded on the fact that the central government was the creation of the provinces which existed before Confederation; they were certainly not abolished by it. Hence, it followed that " $t]$ he Confederation of the British Provinces was the result of a compact entered into by the provinces and the Imperial Parliament, which in enacting the British North America Act, simply ratified it."39

The compact of provinces as the political formula for constitutional change has continued to receive theoretical exposition among Francophone analysts and politicians. ${ }^{40}$ But it was the government of the Province of Ontario under Oliver Mowat that, between 1872 and 1896, took the lead in giving practical expression

35. J. Mallory, The Structure of Canadian Government 24 (1971); see also P. Gérin-Lajoie, Constitutional Amendment in Canada 33, 37-39 (1950).

36. See generally Mallory, Confederation: The Ambiguous Bargain, J. CAN. STUD., July 1977, at 18.

37. G. Mosca, The Ruling Class 70 (H. Kahn trans. 1st ed. 1939). See also Sabetti, Mosca in Canadian Social Science, in Studies on the Political Thought of Gaetano Mosca 165-80 (A. Albertoni ed. 1982).

38. T. LORANGER, LETTERS UPON THE INTERPRETATION OF THE FEDERAL CONSTITUTION KNOWN AS THE BRITISH NORTH AMERICA ACT (1884).

39. Id. at 61 .

40. See, e.g. , R. Ares, Dossier sur le Pacte Fédératif de 1867, La Confédération: Pacte ou Lol? (1967); B. Bissonnette, Essai sur la Constitution du Canada (1963); G. Rémillard, Le FÉdéralisme Canadien 26, 79-122, 165-66 (1980). 
to that formula. The work of Christopher Armstrong ${ }^{41}$ provides a careful and updated analysis of Ontario's relations with the federal government and offers plausible answers to several questions.

Why did Ontario, rather than another province, take the lead in altering the constitutional settlement? Why was Ontario's influence in such remodelling so paramount? As Armstrong suggests,
Mowat recognized that the province occupied a unique place within the Canadian federa- tion, owing to its size, its wealth, and its population. The poorer provinces might look upon federalism as a means of overcoming regional disparities, but Ontario politicians have always valued autonomy more than equality. The province wished to be left alone to develop its bountiful resources, provided that national policies guaranteed it access to mar- kets in other parts of the country. Leaders from Mowat onward, therefore, set out to extend the sway of 'Empire Ontario' and in so doing increase their own power and authority. ${ }^{42}$

The Interprovincial Conference of 1887-hailed by the attending provincial premiers as a new 1864 Quebec conference ${ }^{43}$ _-suggests the point of convergence between Ontario and the other provinces. Whereas all the other premiers, including Quebec's Honoré Mercier, sought economic assistance from the national government, the Ontario premier sought autonomy, though in the interest of maintaining a united provincial stand he went along with their requests for economic concessions. ${ }^{44}$

What factors account for the pressures to remodel the 1867 constitution? First, there was the propensity of provincial leaders to strengthen and increase their own power and authority. In the case of Ontario, this struggle for provincial executive supremacy focused on specific but also "universalistic" issues: 1) boundary disputes with Manitoba; 2) whether the lieutenant-governor was to continue to be a sort of prefect of the national government in the province or whether he should be simply the representative of the monarch in the province as the governor general was in national affairs; 3 ) the control of patronage; 4) the exercise of the dominion power of disallowance over the provincial laws that placed the provincial government under the tutelage of the federal government; and 5) the maintenance of clearly defined, or "water-tight," dual sovereignty jurisdiction in several policy areas over time. ${ }^{45}$ This struggle for jurisdiction was fueled by two other factors: the ability of businessmen to mobilize government for their own ends-propelling the two levels of government into conflict with one another regardless of ties of party solidarity, and the tendency of provincial bureaucrats to defend their sphere of authority against what they saw as federal interference. ${ }^{46}$ Ontario civil servants, fearful that federal government might encroach upon their power to license, regulate, and monitor private companies, "enlisted in [their] battle both their political superiors, who feared the loss of authority and revenues, and certain private interests who, for reasons of their own, preferred to come under [provincial] rather than

41. C. ARMSTrong, supra note 24.

42. Id. at 4.

43. R. CoOK, Provincial Autonomy, Minority Rights and the Compact Theory, 1867-1921, at 41-42 (Studies of the Royal Commission on Bilingualism and Biculturalism No. 4, 1969).

44. Id. ; see also C. ARMSTRONG, supra note 24, at 27-30.

45. See, e.g., C. ARMSTrong, supra note 24, at 14-27.

46. Id. at 85 . 
national jurisdiction." 47 Moreover, the decisions of the Judicial Committee of the Privy Council in favor of provincial jurisdiction and Mowat's political skills and canniness helped to raise the compact of provinces to a first principle of constitutional choice. ${ }^{48}$

The end of the Macdonaldian Constitution ${ }^{49}$ was thus evident well before John A. Macdonald died. French-Canadian Prime Minister Wilfrid Laurier expressed the prevailing view in 1907 when he said that "Confederation is a compact, made originally by four provinces, but adhered to by the nine provinces who have entered it, and I submit to the judgment of this House and to the best consideration of its members, that this compact should not be lightly altered."50 By that time "provincial rights and the compact theory [had] attained a position close to motherhood in the scale of Canadian political values. It would be difficult to find a prominent politician who was not willing to pay at least lip-service to the principle of provincial rights and its theoretical underpinning, the compact theory." 51

Two qualifications must be noted here. First, " $[t]$ here was not the slightest vestige of a 'compact' " in the Acts of Parliament that created the provinces of Alberta and Saskatchewan in 1905. ${ }^{52}$ Second, although Laurier agreed to hold a federal-provincial conference in 1906, to discuss the revision of financial subsidies to the provinces, other constitutional amendments involving the Senate and the House of Commons continued to be made at the behest of the federal parliament alone as late as $1916 .{ }^{53}$ And yet, the fact remains that as Canada emerged from World War I "close to an independent state," 54 it became exceedingly difficult for the federal government to ignore or disregard the constitutional demands of the provinces. As Donald Creighton, a leading historian of Confederation, disparagingly characterized federal-provincial relations of that period:

The 1920's was a great era for the ventilation of provincial rights. Ontario reaffirmed the Compact Theory of Confederation-the theory, that is, that any change in the British North America Act requires the unanimous consent of the provinces. The west contributed the doctrine that the beneficial control of natural resources is historically and constitutionally vested in the provinces-a doctrine which meant that the Dominion, having assumed control of the lands of the western provinces, should now restore what remained of them with compensation. The Maritimes, on their part, presented the thesis of Maritime Rights, in which it was asserted that the Atlantic provinces had been induced to enter Confederation on the strength of certain representations and promises, which had never been fulfilled

47. Id.

48. See the now classic article: Cairns, The Judicial Committee and Its Critics, 4 CAN. J. POL. SCI. 301 (1971).

49. See generally Morton, Confederation, 1870-1896: The End of the Macdonaldian Constitution and the Return to Duality, J. CaN. Stud., May 1966, at 11 , reprinted in Canadian History Since Confederation, ESSAYS AND INTER PRETATIONS 189 (B. Hodgins \& R. Page eds. 1972).

50. Wilfrid Laurier, quoted in Constitutional Issues in CANADA, 1900-1931, at 16 (R. Dawson ed. 1933).

51. R. CoOK, supra note 43 , at 44 .

52. A. Lower, Colony to Nation, A History of Canada 432 (4th ed. rev. 1964).

53. G. Stevenson, Unfulfilled Union: Canadian Federalism and National Unity 210 (1979).

54. A. Lower, supra note 52, at 474; see also O. Skelton, The Canadian Dominion, A Chronicle OF OUR Northern NeIGHBOR 271-74 (The Chronicles of America Vol. 49, 1919). 
and must now be carried out. Broadly speaking, the Dominion surrendered its position in all these matters. ${ }^{55}$

At the Dominion-Provincial Conference of 1927, the sixtieth year of Confederation, the federal government, through Justice Minister Ernest Lapointe, formally recognized and conceded that the provinces had to be consulted about the formula for amending the BNA Act. ${ }^{56}$

The compact of provinces as a political formula accomplished a veritable constitutional revolution in at least three ways. First, the provincial governments were converted from glorified municipalities into coordinate sovereignties in matters of public policy. Second, the provinces acquired the right to be consulted about, and to share in the choice of, the formula for amending the BNA Act. Finally, and most important for future constitutional changes, these transformations gave provincial governments and the federal government authority to determine or set jointly constitutional and institutional arrangements for the provision of public services - in effect, making the process of constitutional decisionmaking virtually indistinguishable from that whereby intergovernmental policy is made in a federal system.

\section{B. The Compact of Peoples}

While the compact of provinces theory of Confederation emerged as an attempt to provide legal support for checking and minimizing the federal government's tutelage over provincial governments and affairs, the compact of peoples theory of Confederation emerged as an attempt to provide moral support for checking and minimizing the consequences of the compact of provinces for the Francophone communities outside Quebec-in essence, to sustain what Mr. Justice Berger of the Supreme Court of British Columbia has recently referred to as "fragile freedoms." 57 The emergence of "provincial rights" gave rise to powerful incentives for a strict application of provincial majority rule and "responsible government"-paralyzing both the BNA Act and the courts as instruments of juridical defense of minority rights. In such circumstances, neither the Monarchy nor its representatives in Canada could act as they were intended to-as a check on the ultimate power of elected politicians and provincial governments. As the settlement of the West transformed the delicate population balance of Canada, Arch-

55. Creighton, Fedetal Relations in Canada Since 19/4, in Canada in Peace and War, Eight Studies in National Trends Since 1914, at 29, 46-47 (C. Martin ed. 1941).

56. This is how the Report of Dominion-Provincial Conference, 1927, phrased it:

In order that adequate safeguard should be provided it was proposed that in the event that ordinary amendments being contemplated the provincial legislature should be consulted, and a majority consent of the provinces obtained, while in the event of vital and fundamental amendments being sought involving such questions as provincial rights, the rights of minorities, or rights generally affecting race, language, and creed, the unanimous consent of the provinces should be obtained.

ConstITUTIONAL Issues IN CANADA, 1900-1931, supra note 50, at 22. The report, id. at 23-24, also makes clear that the Conference divided sharply on the proposal. Some provinces were entirely opposed to the procedure, others either approved of the Minister of Justice's proposal in its entirety or with minor modifications. Although the Dominion government under Mackenzie King decided, as a result, to let the matter drop, the principle that provinces were entitled to be consulted about the formula for amending the BNA remained. See also P. GÉRIN-LAJOIE, supra note 35, at 228-30.

57. T. Berger, Fragile Freedoms: Human Rights and Dissent in Canada (1981). 
bishop Tache, the ecclesiastical and national leader of the French Canadians in Manitoba, foresaw the outcome: "Number is going to make us weak, . . . and since under our constitutional system number is power, we are going to find ourselves at the mercy of those who do not love us." 58

Beginning in New Brunswick in the 1870's, in Manitoba in the 1880's, then in the newly created provinces of Alberta and Saskatchewan in 1905, and finally in Ontario in 1912 and Eastern Canada as a whole by 1920, the linguistic and educational rights of the various French Catholic communities were challenged by responsible government, with relative immunity. ${ }^{59}$ In an effort to minimize or prevent this tyranny of the majority or privileged minority, Francophone lay and religious leaders turned to the compact of peoples as the implied moral and metaphysical base of Confederation.

Henri Bourassa, a Catholic thinker and founder of the influential Montreal newspaper Le Devoir, emerged as the most eloquent user of this political formula as a means to insure the survival of Canadian duality. ${ }^{60} \mathrm{He}$ frequently asserted that mutual respect was "the only ground upon which it is possible for us to meet so as to work out our national problems. There are here neither masters nor valets; there are neither conquerors nor conquered ones; there are two partners whose partnership was entered into upon fair and well-defined lines."61 He averred that the making of Canada in 1867 represented, in the final analysis, "the free and voluntary association of two peoples, enjoying equal rights in all matters."62 Bourassa warned that "[i]f the Canadian constitution is to last, if the Canadian Confederation is to be maintained, the narrow attitude towards minorities which increasingly manifests itself in the English provinces must disappear, and we must return to the original spirit of the alliance."63 The original spirit of Confederation was, for the founder of Le Devoir, best exemplified by what was taking place in Quebec:

The vast majority of its people speak French, but they grant to the English-speaking minority the right to speak English freely, and they accord them in the local administrations, municipal or provincial, those facilities which we ask in federal affairs, not merely as a matter of right-I would never put the question on that narrow basis- but as a matter of

58. R. CoOK, Canada AND the French-Canadian Question 183 (1966)(emphasis added); see also R. Brown \& R. CoOk, Canada 1896-1921, A Nation Transformed 2-5, 60-73 (1974); Cook, The Paradox of Quebec, in ENTERing the Eighties: CaNADA IN CRISIS 49-51 (R. Carty \& W. Wards eds. 1981).

59. See generally T. BERGER, supra note 57, at 19-21, 26-89; R. Brown \& R. COOK, supra note 58, at 1218, 75-78; L. Clark, The Manitoba School Question: Majortty Rule or Minority Rights? (1968); R. CoOK, The Polttics of John W. Dafoe and the Free Press 69-70 (1963); A. Lower, supra note 52, at 399-402, 421; W. MORTON, The KINGdOM OF Canada 371-72, 380-81, $432-35$ (1963); W. MORTON, supra note 27, at 259, 269; Staples, Consociationalism at Arovincial Level: The Erosion of Dualism in Manitoba, 1870-1890, in Consociational Democracy, Polmtical Accommodation in Segmented Societies 288 (K. McRae ed. 1974); M. Wade, The French Canadians 1760-1967, at 433-40, 537-45 (rev. ed. 1975).

60. The following works provide a helpful introduction to Bourassa's thought and action: Davenport, Nationalism and Conciliation. The Bourassa-Herizog Posture, 44 CAN. HIsT. Rev. 193 (1963); Laurendeau, Henri Bourassa, in Our Living Tradition, Fourth Series 135-58 (R. McDougall ed. 1962); Levitt, Henti Bourassa and Modem Industrial Society, 50 CAN. HIST. REV. $37-50$ (1969); O'Connell, The Ideas of Henri Bourassa, 19 CAN. J. ECON. \& POL. ScI. 361 (1953); 2 M. WADE, supra note 59, at 617-65.

61. R. COOK, supra note 58, at 107.

62. Id. at 51.

63. $2 \mathrm{M}$. WADE, supra note 59 , at 618 . 
common sense, and true Canadian spirit, so as to spread out into every province of Canada the same spirit of Canadian citizenship which exists in Quebec, and should exist everywhere in the Dominion. ${ }^{64}$

The history of Quebec is not free of ethnic prejudice, nativistic discrimination, and religious intolerance-at times even against non-French Catholics. But this history does not greatly undermine Bourassa's compact of peoples. As André Laurendeau, a committed Quebec nationalist and co-chairman of the Royal Commission on Bilinguilism and Biculturalism of the 1960's, noted, "Bourassa defended the rights of his own . . . [, the] French Canadians; but he always chose to do so in terms that were valid for all."65

Bourassa's appeal to an implied covenantal base of Confederation was not heeded, however. Protestant and English Canadians, well familiar with covenantal thought, failed to extend that tradition to French Canadians. As Ramsay Cook explained in Provincial Autonomy, Minority Rights and the Compact Theory, 1867$1921,{ }^{66}$ Bourassa's compact of peoples formula for constitutional choice

\begin{abstract}
had on its side none of the powerful influences which had played so large a part in gaining wide acceptace for the theory of the compact of provinces. No political party adopted it as part of its platform . . . . Nor did the theory win the whole-hearted approval of powerful provincial governments; indeed to the extent that it implied a limitation on provincial powers, it went against the views of most of the provinces. Not even the province of Quebec . . . adopted the theory in any consistent fashion. Finally, the compact of [peoples], unlike the theory of the compact of provinces, won no support from the Judicial Committee of the Privy Council . . . In light of these observations, it is not surprising that the concept of the cultural compact of Confederation remained the possession of only a small minority of Canadians. ${ }^{67}$
\end{abstract}

What became known as "the Anglo-Saxon Kulturkampf" followed, sweeping away French-language rights outside Quebec 68 -in effect, lending credence to de Tocqueville's observation that "the extension of judicial power in the political world ought . . . to be in the exact ratio of the extension of elective power. If these two institutions do not go hand-in-hand, the state must fall into anarchy or into servitude." 69

It has been suggested that French Canadians then had "the proof that the English Canadians-at least a noisy and powerful group among them-did not accept French Canada as an equal partner."7o Yet, at least until World War II, most French-Canadian nationalists clung to the hope that some day they would receive equitable treatment outside Quebec. ${ }^{71}$ It is fair to recall another item of "proof:" Quebec's failure to adopt the compact of peoples in any consistent fashion gave English Canadians "proof" that the Quebec governing class was like

64. Quoted in $\mathbf{R}$. CoOK, supra note 58 , at 39 .

65. Laurendeau, supra note 60 , at $135,145$.

66. R. CoOK, supra note 43.

67. Id. at 63.

68. See supre note 59.

69. 1 A. De Tocoueville, Democracy in America 77 (P. Bradley ed. New York 1954)(1st ed. Paris 1835).

70. Brunet, The French Canadians' Search for a Fatherland, in NATIONALISM IN CANADA 47, 55 (P. Russell ed. 1966).

71. See Royal Commission of Inquiry on Constitutional Problems, The Tremblay Report (D. Kwavnick ed. 1973). 
that of all other provinces. ${ }^{72}$ Against this backdrop of Confederation transformed, the second phase of constitutional change occurred.

\section{III}

\section{The Second Phase of Constitutional Change}

The "agreement" reached at the 1927 federal-provincial conference ${ }^{73}$ ended the first phase of constitutional change. But it also virtually insured that no area of public economy could not henceforth be potentially subject to "federal-provincial diplomacy"74 and be dealt with on the basis of unanimous consent. As a result, the search for an amending formula for the constitution that could at the same time appropriately locate and fix "power somewhere" 75 in the face of changing public economies and changing political contingencies proved to be exceedingly difficult and costly in time and effort.

\section{A. Attempts to Amend the Constitution}

The 1927 federal-provincial conference was followed by others in 1931, 1933, $1934,1935,1936,1941,1945,1950,1955$, and 1957, to reach an unprecedented number, activity, and scope in the 1960's and 1970's. The "category" approach to constitutional amendments adopted in $1927^{76}$ was refined in the 1935-36 negotiations. Constitutional provisions were divided into four categories: 1) those affecting the Dominion alone would be amended by Parliament; 2) those affecting the Dominion and some but not all the provinces would be amended by the consent of the parties involved; 3) those affecting fundamental rights such as civil law in Quebec and linguistic and educational provisions would require the unanimous consent of Parliament and all the provincial legislatures; and 4) all other matters would need the approval of six of the nine provinces, and those six must contain fifty-five percent of the total population. ${ }^{77}$ This category approach became the basis of all subsequent federal-provicial negotiations and was further refined between 1960 and 1966 by what became known as the Fulton-Favreau Formula. ${ }^{78}$

72. See generally G. Glazebrook, A History of Canadian Poltrical Thought 328 (1966).

73. See supre note 56.

74. See genetally R. Simeon, federal-Provincial Diplomacy: The Making of Recent Policy IN Canada (1972).

75. For evidence of this tradition of thought and action among students and practitioners of Canadian politics see, e.g., Cairns, Altemative Slyles in the Siudy of Canadian Politics, 7 CaN. J. POL. SCI. 101 (1974); Sproule-Jones, An Analysis of Canadian Federalism, Publius 110-13 (1974); Sabetti, Reflections on Canadian Urban Govemence Research, 8 COMP. URB. RESEARCH 87-112 (1981).

76. The standard account for this history is P. GÉRIN-LAJOIE, supra note 35, at 234-49; see also C. ARMSTRONG, supra note 24, at 199-206.

77. C. ARMSTRONG, supra note 24, at 205-06.

78. The post-World War II search for an amending formula that culminated in the Fulton-Favreau Formula is aptly traced in J. Mallory, The Structure of Canadian Government 379-86 (1971). Mallory described the Fulton-Favreau Formula in the following terms: the formula "dealt with the problem of section 91(1) of the BNA Act (the 1949 amending formula) by revising it and incorporating it, together with a revised form of the provincial amending power in section 92(1), into the proposed amending procedure. The power of Parliament to amend the constitution was more specifically defined as applying to 'the Constitution of Canada in relation to the executive Government of Canada and the Senate and the House of Commons." Id. at 384. Some additions were also inserted to protect provincial representation in the Senate and in the House of Commons. 
The category approach failed to reform the constitution but it did produce ad hoc financial arrangements for unemployment and relief in the Depression ${ }^{79}$ and, by 1940 , a national unemployment insurance plan. ${ }^{80}$ After the war, the same approach served to introduce considerable flexibility and adjustment in intergovernmental relations concerned with the provision of public services. ${ }^{81}$ The earlier ad hoc arrangements for employment and relief grew into conditional and unconditional grants to provinces. This federal spending, together with the delegation of federal powers to provincial agencies and the creation of ad hoc or standing intergovernmental committees, created the basis of what, particularly under the Pearson government, became known as "cooperative federalism." 82 This cooperative federalism overshadowed the constitutional impasse but made it more difficult to overcome, because the federal government, in its desire to accommodate the Quebec government under Jean Lasage, acted as if almost everything was negotiable-even what seemed, to some, essential to the effective functioning of Canadian federalism. Little wonder, then, that by the time the centennial of Confederation approached there was in many quarters considerable skepticism about the very credentials of Canadian constitutional arrangements. As one observer noted, "By . . . 1966, the Canadian federal system had reached one of the most severe crises in its history." 83

The failure of the piecemeal approach to constitutional change led in the late 1960's to a more comprehensive approach under the new Liberal and more centralist Prime Minister, Pierre Elliot Trudeau, whose task was in turn made easier by successive changes in the Quebec premiership after Lesage-Daniel Johnson, Jean-Jacques Bertrand, and Robert Bourassa. This approach involved the entrenchment of official language rights, a bill of rights, and equalization payments to provinces. This comprehensive approach helped to produce what became known as the Victoria Charter Formula between 1968 and $1971 .^{84}$ But its very comprehensiveness could not obscure the fact that it ignored or glossed over division of power questions so crucial to Quebec. As the then Quebec Deputy Minister of Intergovernmental Affairs later explained Quebec's veto: "The charter completely missed the real Canadian problem, that of the place of Quebec and the Quebec nation in Canada. What is more, Quebec's acceptance would have

79. C. ARMSTRONG, supra note 24 , at $148-59$.

80. Id. at 209-12, 219-20.

81. E.g., D. Smiley, Constitutional Adaptation and Canadian Federalism Since 1945 (1970).

82. Cooperative federalism is defined in the Canadian context as a series of pragmatic and piecemeal responses by the federal and provincial governments to the provision of public services involving mutual interdependence. See generally D. SMILEY, supra note 81, at 111-28.

83. D. Smiley, The Canadian Political Nationality 84 (1967).

84. In addition to the points mentioned in the text, the Victoria Charter had a procedure whereby the most important parts of the Canadian Constitution could be amended by resolution of the Senate and House of Commons and of at least a majority of the provinces which included: (1) each province with a population of at least $25 \%$ of the population of Canada (in effect, Ontario and Quebec); (2) at least two of the Atlantic provinces; and (3) at least two of the western provinces having together at least half of the population of all western provinces. In brief, the procedure of the Victoria Charter diverged from both existing practice and the Fulton-Favreau Formula by not requiring unanimous provincial consent for iniportani amendments. 
amounted to a denial of the problem's very existence."85 Thus the Victoria Charter failed to receive the needed consensus to make it operational, closing yet another round of constitutional negotiations.

The end of the Trudeau minority government in 1974 was accompanied by renewed intergovernmental efforts to patriate and amend the BNA Act, lasting until the very end of the 1970's. But the flurry of activities that accompanied the accession to power of the independentiste Parti-Québécois in 1976, ${ }^{86}$ the rise of the "New West" in Alberta, ${ }^{87}$ the success of the Progressive Conservative party defeat of the Liberal party in the 1979 federal elections, and the return to power of the Liberal party under Trudeau in the January 1980 federal elections ${ }^{88}$ could neither lessen nor overcome the constitutional stalemate. Conjectures that Canada would be entering the eighties in crisis ${ }^{89}$ did not seem too inappropriate or exaggerated.

Thus the second phase of constitutional change was plagued by insurmountable difficulties in amending and patriating the constitution and by intergovernmental instability in the provision of public services. Little purpose will be served here by tracing ad plenum the tangled federal-provincial diplomacy that shaped and accompanied constitutional negotiations and intergovernmental relations between 1927 and 1980 and the many-colored reports of government commissions, task forces, and political parties that the not-so-successful federal-provincial diplomacy generated. 90 Instead, the answers to the following set of questions will be attempted: Why did the great quantity of energy devoted to constitutional decisionmaking over the course of about fifty years produce minimal results? What factors account for the difficulties and deadlocks in constitutional negotiations? What reasons best explain the instability of intergovernmental arrangements for the provision of public services?

\section{B. Sources of Instability and Stalemate}

Several plausible factors causing the deadlock in constitutional negotiations

85. C. Morin, Quebec versus OTtaWa: The Struggle for Self-Government 1960-72, at 69 (1976). See also E. MCWhinney, Quebec and The Constrtution 1960-1978, at 24-26 (1979).

86. As the independentist Quebec government began preparations for how Quebec could peacefully become a sovereign nation-state, in association with or independent from Canada, the Trudeau government in 1977 established a Task Force on Canadian Unity headed by a former Liberal federal cabinet minister from Quebec and a former premier of Ontario, while the Quebec provincial liberals eventually chose Claude Ryan, a much respected and highly regarded editor for Le Devoir, to lead them and, in effect, to thwart separatist designs. Academicians also joined in these events by providing analyses and proposals such as those in Must Canada FaIL? (R. Simeon ed. 1977).

87. See generally Pratt, The Stale and Province-Building: Alberla's Development Stralegy, in THE CANADIAN State: Political Economy and Political Power 133-64 (L. Panitch ed. 1977).

88. See generally Canada at The Polls, 1979 and 1980, A Study of the General Elections (H. Penniman ed. 1981).

89. See Entering the Eighties: Canada in Crisis (R. Carty \& W. Wards eds. 1981).

90. In addition to $R$. Simeon, supra note 74 , see also TASK Force On Canadian UNITY, A FUTURE TOGether (3 vols. 1979); blue colored Government of Quebec, Quebec-Canada: A New Deal: The Quebec Government Proposal for a New Partnership Between Equals: Sovereignty Association (1979); Smiley, The Association Dimension of Sovereignty-Association: A Response to the Quebec White Paper (Discussion Paper No. 8 of the Institute of Intergovernmental Relations, Queen's University, Kingston, Ontario, 1980); and Constitutional CommrtTeE of THE QUEBEC Liberal Party, a New Canadian Federation (1980). 
loom large. These factors can be divided into two interrelated but analytically distinct categories: extrinsic reasons which are outside of constitutional arrangements proper, and intrinsic reasons which are due to defects or shortcomings in constitutional arrangements themselves. The principal extrinsic factors were identified by the Task Force on Canadian Unity with the following statement and prognostication: "Duality and regionalism lie at the heart of the Confederation crisis [and] . . . any general reform effort, however well intended, which fails to enhance duality or which offends the principle of regionalism is unlikely to increase harmony and unity in Canada."91 The principal intrinsic factor was suggested by Mark Sproule-Jones's question: "What consequences are likely to ensue when constitutional arrangements are jointly determined by an exclusive group of eleven governments, governments that individually act as 'teams' . . . ?"92 Each of these three factors is considered below.

1. Canadian Duality. Canadian duality is a summary phrase which stands for mutually proper, fair, and just political relationships between English-speaking and French-speaking Canadians. The Anglo-Saxon Kulturkampf against the French and the rejection of the compact of peoples during the first phase of constitutional change seriously undermined Canadian duality, with little threat to the territorial integrity of Canada. But the French Kulturkampf for survival since then has posed and continues to pose a serious threat to the territorial integrity of Canada.

It has often been asserted that "[ $t]$ he refusal of the majority in English-speaking Canada to uphold the linguistic rights and therefore the cultural integrity of the minority led that minority to assert that it should have, indisputably and where it could exercise it, the political power necessary to insure its survival: If [Georges Etienne] Cartier became [Henri] Bourassa, Bourassa, owing in part to the fate of the bicultural idea in English Canada, became Michel Brunet."93 The identification by French Canadian nationalists of their country with the province of Quebec alone contributed, no doubt, to what Michel Brunet (a Quebec nationalist historian) called the end of the French Canadians' long search for a fatherland. ${ }^{94}$ But the end of this long search was empirically grounded and manifested in the social, economic, and political transformations that reached unprecedented levels with the end of the Duplessis regime in $1959 .{ }^{95}$

The societal transformations were encouraged, sustained, and given purpose by the bureaucratic and political imperatives of provincial state building and omnicompetence.96 These transformations not only led to a new "language ques-

91. 1 Task Force on Canadian Unity, A Future Together 36 (1979).

92. Sproule-Jones, supra note 75, at 109, 123; see also Sproule-Jones, Public Choice and Federalism in Australia and Canada (Canberra Center for Research on Federal Financial Relations Research Monograph No. 11, 1975)

93. Smith, Metaphor and Nationality in North America, 51 CAN. Hist. Rev. 247, 269 (1970).

94. Brunet, supra note 70 , at 60 .

95. E.g., C. Black, Duplessis (1977); K. McRoberts \& D. Posgate, Quebec: Social Change and Polrtical Crisis (1976).

96. Bolduc \& Gow, Environment and Administration: Quebec, 1867-1980, in The ADMINISTRATIVE STATE in Canada 31, 46-56 (O. Dwivedi ed. 1982); see also K. MCRoberts \& D. Posgate, supro note 95, at 96129. 
tion" in Quebec itself that revealed fully the precarious freedoms of access to equal public services enjoyed by Canadians of non-French and non-English origin. ${ }^{97}$ But they atso created an almost unprecedented case for "Quebec versus Ottawa"98 that neither the federal nor the other provincial ruling classes of Canada could ignore or deny without danger. In the course of the 1960's and 1970's, there thus developed a situation whereby, as the ten governments tried to accommodate Quebec's struggle for jurisdiction in several policy areas, the Quebec government, under different parties and leaders, came to view the very patriation and reform of the Canadian Constitution as potential checks on Quebec's own "unfinished revolution."99 The decisional rules that applied to federal-provincial negotiations ultimately served to insure that the Fulton-Favreau and the Victoria Charter formulae would remain just that. The defeat of the Parti Québécois Proposal of a sovereignty-association between Quebec and Canada in the 1980 May referendum could neither remove Canadian duality from question nor finish "Quebec's unfinished revolution."

2. Regionalism. It is generally recognized that regionalism was and has been one of the most consistent and hardy factors for "limited identities"100 in Canada since Confederation. Although the roots and strength of regionalism are difficult to measure and although regional interests may not be the same as provincial government interests, ${ }^{101}$ provincial governments have historically been important agencies for regional movements, demands, and protests.

As we have already seen, the compact of provinces was used as a political formula to justify and effect a veritable revolution in federal-provincial relations. As a consequence, even the Depression failed to persuade many provincial leaders that the problem of the modern, industrial state could be met only through the centralization of power in Ottawa. ${ }^{102}$ More recently, interprovincial conferences have become important forums for interprovincial bargaining and for developing joint positions to take to Ottawa. ${ }^{103}$ The growth of what has been called "prairie capitalism"104 is one of the most powerful expressions of regionalism since World War II. The defeat of the Social Credit government of Alberta in 1971 by the Progressive Conservative Party brought to an end a long period of government conservatism and began a new era of "interventionist, 'positive' government . . . employed to nurture the development, and to defend the province-building interests, of an ascendant class of indigenous business entrepreneurs, urban profes-

97. Some of the consequences of the French-language legislation (Bills 22 and 101) are traced and discussed throughout S. ARnopoulos \& D. Clift, The English Fact in Quebec (1980).

98. See generally C. MORIN, supra note 85.

99. See generally L. DiON, QUebec: The Unfinished Revolution (T. Romer trans. 1976); see also the article by Daniel Latouche in this issue of LAW \& CONTEMP. PROBS.

100. Careless, "Limited Identities" in Canada, 50 CAN. HIST. REV. 1 (1969). (1980).

101. Simeon, Intergovernmental Relations and the Challenges to Canadian Federalism, 23 CAN. PUB. AD. 14, 26

102. See generally J. Mallory, Social Credit and the Federal Power in Canada (1st ed. 1954).

103. See Leach, Interprovincial Co-operation: Neglected Aspect of Canadian Federalism, 2 CAN. PUB. AD. 83 (1959); Simeon, supra note 101, at 21.

104. See J. Richards \& L. Pratt, Prairie Capitalism: Power and Influence in the New WEST (1979). 
sionals, and state adminstrators." 105 As a result, the post-Victoria rounds of federal-provincial negotiations were characterized by a considerable struggle for jurisdiction over culture, communications, and the federal spending power, as well as natural resources. Alberta and Quebec were not the only provinces to engage in this struggle for jurisdiction with Ottawa. ${ }^{106}$

The growth of regionalism necessarily implied an increasing interdependence and sharing of responsibilities with the federal government. But federal-provincial negotiations were structured so as to hinder rather than facilitate federal-provincial interdependence and partnership.

3. Constitutional Arrangements as Executive-Determined Facilities. Standard accounts of Canadian federal-provincial instability and constitutional stalemate start with the assumption that constitutional arrangements are as a rule set jointly by the executive-dominated governments acting individually as constitutional decisionmakers. As the writings of Alan Cairns ${ }^{107}$ indicate, the shortcoming in this approach is to take as given what should be taken as problematic. The chief value of Sproule-Jones's analysis of Canadian federalism ${ }^{108}$ consists in reversing the order by considering what consequences are likely to ensue when constitutional arrangements are jointly determined by an exclusive group of eleven governments requiring unanimous consent.

First, the provincial and federal governments of Canada resisted all attempts to include other public or private persons from sharing in the setting up of constitutional arrangements. Exclusion was rigidly maintained. The controversy surrounding the Statute of Westminster ${ }^{109}$ in $1930-1931$ is a case in point. By removing all constitutional limitations on the sovereignty of the British Dominions, the Statute of Westminster appeared, in effect, to transfer the power to amend the BNA Act from the British Parliament to the parliament of Canada without necessarily the consent of provincial legislators. Provincial governments successfully pressured the national government to secure a clause in the Statute of Westminster exempting the BNA Act from the effect of the Statute and thereby maintaining their role as agents of constitutional choice. ${ }^{110}$ Another example is furnished by the Royal Commission on Dominion-Provincial Relations, the Rowell-Sirois Commission, mandated by the federal government in 1937 to examine the economic and financial basis of Confederation, the distribution of legislative responsibility, and the financial relations between governments. ${ }^{11}$ For their centralist bias on many policy issues, members of the commission were hailed in some quarters as "the new Fathers of Confederation" 112 but this view was stren-

105. Pratt, supra note 87 , at 133.

106. See J. Meekinson, Canadian Federalism: Myth or Reality 140-87, $280-365$ (3d ed. 1977).

107. See Cairns, The Other Crisis of Canadian Federalism, 22 CAN. PuB. AD. 175-95 (1979); Cairns, The Governments and Sacieties of Canadian Federalism, 10 CAN. J. POL. SCI. 695-726 (1977).

108. Sec M. Sproule-Jones, supra note 92; Sproule-Jones, supra note 75, at 109.

109. The Statute of Westminster, 1931, 22 Geo. 5, ch. 4.

110. See C. ARMSTRONG, supra note 24, at 146-48.

111. The Rowell-Sirois Report, The Carleton Library No. 5 (D. Smiley ed. 1963)(an abridgment of Book 1 of the Royal Commission Report on Dominion-Provincial Relations, 1940).

112. See, e.g., Creighton, supra note 55, at 56. See also Alway, Hepbum, King, and the Rowell-Sirois Commission, 48 Can. Hist. Rev. 113 (1967). Smiley, The Rowell-Sirois Report, Provincial Autonomy, and Post-War 
uously opposed in words and deeds by several provincial premiers. More recently, attempts to entrench a bill or charter of human rights by Prime Minister Diefenbaker in the late fifties and by Trudeau in the late sixties and seventies failed to secure unanimous consent because such charters transferred, or appeared to transfer, a substantial amount of authority from the legislatures to the courts. ${ }^{113}$

A second consequence of the joint supply of constitutional arrangements by the exclusive club of eleven governments was put in this way by one observer: "[R]edrafting [the constitution] is hard enough in Canada. It becomes immensely more complicated when too many people want to use the occasion to solve all the country's political problems at the same time-as well as design new rules for determining the framework for tackling these very problems."114 Several other consequences occurred when the governments attempted formal or tacit coordinated behavior. Each government had an incentive to be the sole supplier (i.e., exclude each other from the provision) of public services within its jurisdiction, while enlisting the other governments in sharing the costs of programs. At the same time, each government had an incentive to prevent another from raiding its treasury to provide services that are nonconsumable within its own jurisdiction. As a result, each government had to ensure that new or extended programs undertaken by other governments met with its own willing consent. There must either have been unanimous approval or no coordinated action was viable. ${ }^{115}$

Sproule-Jones noted three other consequences that flowed from the logic requiring unanimous consent for federal-provincial initiatives. As the history of the different patriation formulae between 1935 and 1979 suggests, one consequence of unanimous consent was to grant any holdout extraordinary bargaining power. ${ }^{116}$ As a condition of giving its consent, any holdout government was able to demand a much larger than proportionate share of its payoffs from the group activity. Quebec has not been the only government to engage in frequent holdout tactics, ${ }^{117}$ although its reasons differ from those of the other provinces. The result in the post-World War II period was a series of complex and evolving fiscal arrangements and equalization schemes, as well as the establishment of the "welfare-state"-whose eventual modifications, subject as they were to other rounds of bargaining costs, plus any side payments to take account of holdout strategies of one or more governments, carried with them their own source of instability. ${ }^{118}$

Another consequence was the prevalence of logrolling. ${ }^{119}$ Governments were willing to give consent on certain matters strongly preferred by other governments, in exchange for their support on matters which the first government preferred

Canadian Federalism, 28 CAN. J. ECON. Pol. SCI. 54 (1962), notes correctly that "[i]n spite of the scope and quality of the commission's work, its analysis of federal-provincial relations has had surprisingly little influence on the direction that the theory and practice of Canadian federalism have taken since 1945."

113. Sproule-Jones, supre note 75, at 124. See Laskin, An Inquiry into the Diefenbaker Bill of Rights, 37

CAN. B. REv. 77 (1959).

114. Black, Federal-Provincial Confences and Constitutional Change, 78 QUEEN's Q. 298, 298 (1971).

115. Sproule-Jones, supra note 75 , at 124-25.

116. Id. at 125.

117. Id. See also C. MORIN, supra note 85, at 69 and E. MCWHINNEY, supra note 85, at 24-26.

118. Sproule-Jones, supra note 75 , at 125 , and $\mathrm{nn}$. $54,55 \& 56$ cited therein.

119. Id. at 126 . 
intensely. The Canada Pension Plan of 1966 and the different opting-out procedures were some of the most evident results. ${ }^{120}$

The final consequence of the unanimous consent procedure is the bargaining costs in time and effort that each government was forced to bear over the course of fifty or more years. ${ }^{121}$ The institutionalized machinery of federal-provincial relations become more and more complicated by the 1960's. ${ }^{122}$ Formal meetings, conferences, and committee meetings among civil servants and occasionally ministers of the eleven governments became frequent occurrences-increasing the bargaining costs. Sproule-Jones suggested that another reason for the increase in bargaining costs was that each government had an incentive to monitor the operations and initiatives of the other governments, for fear of being left out from future deliberations. ${ }^{123}$ The growth of provincial intergovernmental relations ministries was, no doubt, partly due to this. The outcome was an increased size of the bargaining costs encountered by each government as time progressed.

As a result, the joint supply of constitutional arrangements by the exclusive groups of governments led to the rigid exclusion of other individuals or collective bodies from sharing in the setting of constitutional arrangements. It led to a variety of ways in which public goods and services were delivered and amending formulae conceptualized. The post-fifties period was characterized by an unequaled level of federal-provincial negotiations and relations. But the dictates of federal and provincial bargaining, together with the pressures of Quebec nationalism and regionalism more generally, insured that none of the ways in which collective services were delivered and constitutional changes proposed would remain stable or secure for too long. Minimal results in constitutional reform and inherent instability in intergovernmental relations have been the signal features of some fifty years of attempted constitutional change in Canada.

IV

\section{Implications for the Third Phase of Constitutional Change}

The making of Canada was one of the most notable achievements in the nineteenth century. Unlike some other countries, Canada was established by peaceful means within an international imperium. A new political economy experiment was created by fusing together two seemingly antithetical principles of organization: federalism and responsible government. The novelty of this experiment attracted the attention of an Italian publicist, Enea Cavalieri, ${ }^{124}$ who in 1876 travelled throughout most of what was then Canada to see how the new social, economic, and political order worked. He remarked in his travel notes that all the reading he

120. Id.

121. Id.

122. Id.

123. Id.

124. Enea Cavalieri is perhaps best known for the work he did with L. Franchetti and Sidney Sonnino on Sicilian rural conditions in 1876. In fact he left Sicily to visit Canada and the United States. His book on North America is entitled IN GIRO DEL MONDO: OsSER VAZIONI ED APPUNTI (1880) and is divided into two parts: Part I, consisting of 17 chapters, deals with Canada; Part II, consisting of 20 chapters, deals with the United States. 
had done on North America had not prepared him for what he found: a union of various colonies and peoples in a single and great Dominion. Europe paid little attention to this new country, but, suggested Cavalieri, its constitutional development, public economy, and law were worth knowing and studying. Canadian Confederation signalled the beginning of a new political economy equilibrium in North America and presaged the possibility of novel solutions to contemporary problems in Europe. ${ }^{125}$

Flaws in its original creation made Canada highly unstable in some important respects. Yet, the flaws that made Confederation highly unstable also served to insure its very existence. Such was the view of Andrew Pattullo, an Ontario journalist and legislator, as he praised Mowat's leadership in pressing for constitutional change between 1872 and $1896 .{ }^{126}$ Contemporary historians of Canadian federalism tend to side with Pattullo. They suggest that previous generations of historians and political scientists have dealt too harshly with the compact of provinces theory of Confederation and with premiers such as Ontario's Mitchell Hepburn. ${ }^{127}$ But, as we have hinted in the discussion of the compact of peoples and the second phase of constitutional change, the benefits from the first phase of constitutional change are not easy to reckon.

- Trudeau's last attempt to patriate and amend the BNA Act succeeded in overcoming the stalemate, in part because it began unilaterally and in part because it was achieved without unanimous consent (Quebec dissenting). To be sure, there had been threats of unilateral action before by Trudeau and other prime ministers. What factors account for Trudeau's urgency to press ahead? Why did he succeed when all others failed? ${ }^{128}$ No doubt, these are features of the Trudeau partriation package that will receive considerable scholarly attention in the future-as they should. But other features of Trudeau's patriation package appear equally worthy of study.

The proclamation of the Canadian Constitution of 1982 ends a long phase of crisis, stalemate, and minimal results and begins a phase of constitutional decisionmaking that seems to bear little relationship to the past. What implications, if any, do the previous phases of constitutional change have for the new one?

Canadian dualism or the place of Quebec in Confederation will continue to tax the new constitutional arrangements as will the forces of regionalism or provincial state building. More fundamentally, as long as federal and provincial executives continue to jointly determine constitutional arrangements, and as long as the present practice of parliamentary government continues, the third phase of constitutional change will be characterized by considerable institutional weakness and failure. Robin W. Boadway and Kenneth $H$. Norrie in their recent analysis of "Constitutional Reform Canadian-Style" warned of somewhat similar consequences:

125. Id. at 196-97.

126. See C. ARMSTRONG, supra note 24 , at 32.

127. Id. See also Mallory, Style and Fashion: A Note on Altemative Styles in Canadian Political Science, 7 CAN. J. POL. 129 (1974).

128. D. Smiley, Canada in Question: Federalism in the Eighties 88 (3d ed. 1980). 
[B]y turning the task over to the first ministers we are necessarily severely restricting the kind of constitutional change we might expect. We are guaranteeing that the process will be one of strategic bargaining by eleven self-interested participants. There will be no opportunity to present and discuss alternative constitutional arrangements that might more effectively provide public goods to the population. This is especially true of proposals that would significantly alter the authority of both existing levels of government. Not only does the process itself preclude other options, however, but it also seems slated to deliver us a result that might actually be undesirable. ${ }^{129}$

The Charter in the 1982 Constitution may, however, open up the process of participation in constitutional change through citizen litigation which may, in turn, enhance the role of the courts in conflict management. ${ }^{130}$ This means that the Charter could become an important source of instability and crisis for "parliamentary majoritarian democracy" a la McRuer Report ${ }^{131}$ in, and outside of, Ontario.

There is no interest in straitjacketing, albeit if only with the power of words, Canadian constitutional development. As Milovan Djilas has observed, "History does not exactly abound with instances of thinkers' predictions having come true, least of all those relating to social patterns and people's attitudes and ways of life." 132 The adaptive potential of the Canadian people encourages "a bias for hope." ${ }^{133}$ And yet, the preceding analysis suggests that there is little or no prospect for changing the executive-centered system of government in Canada. At the same time, knowledge of the basic rules that are applicable to the governance of Canadian society may be lost as people become spectators of federal-provincial conflict and state pageantry. A situation may develop whereby as Canadians become increasingly prone to speak the language of doubt when describing their society, ${ }^{134}$ they will be unable to conceptualize political solutions appropriate to their exigencies. But, it is precisely here that political scientists can make a contribution. Their task is not to tend to the system, but rather to assess its performance. ${ }^{135}$ For this reason there is much to learn or unlearn from the study of the historical context of the Constitution of 1982. A new understanding of Canadian Federalism is needed before contemporary problems can be resolved.

129. R. Boadway \& K. Norrie, Constitutional Reform Canadian-Style: An Economic Perspective, 6 CAN. PUB. POL'y 492, 494 (1980).

130. See generally Mallory, Conftict Management in the Canadian Federal System, LAw \& ConTEMP. ProBS., Summer 1981, at 231. See also T. BERGER, supra note 57, at 258, 260-262.

131. See generally Smiley, The McRuer Report: Parliamentary Majoritarian Democracy and Humen Rights, J. Can. Stud., July 1970 , at 3 .

132. M. DJILAS, The UNPERFEct SOCIETy 150 (1969).

133. A. HIRSCHMAN, A BIAS FOR HOPE (1971)(to borrow a phrase from another context).

134. D. Bell \& L. TePperman, supra note 2, at 6 . The authors noted:

A group of Western and Maritime Canadian intellectuals brooded over the "burden of unity"; at the same time, their colleagues from Ontario asked the ominous question "Must Canada fail?" A philosopher has offered a "lament" for Canada, an economist has documented its "silent surrender," and a political scientist has called into "question" Canada's continued existence. According to other writers, Canada is a "nation unaware" of its past and uncertain of its future. Our legendary capacity for

"survival" stands threatened by internal strains, "divided loyalties" and foreign "dominance."

Id. Bell and Tepperman themselves contributed to this list by entitling their book THE ROOTS OF DisuniTY.

135. For a beginning in this direction see especially Cairns, supra note 75, and Sproule-Jones, supra notes 5,75 , and 92 . 